\title{
POTENTIAL ANALYSIS OF ASIAN TOAD (DUTTAPHRYNUS MELANOSTICTUS) AS A CONTROLLER OF HARMFUL INSECTS AND THEIR SUBSTITUTIONS IN ELEMENTARY SCHOOL SCIENCE LESSONS
}

\author{
${\text { Muhammad Syazali }{ }^{1} \text {, I Putu Artayasa }}^{2}$, and Mohammad Liwa Ilhamdi ${ }^{2 *}$ \\ ${ }^{1}$ Program Studi Pendidikan Guru Sekolah Dasar, FKIP Universitas Mataram, Indonesia \\ ${ }^{2}$ Program Studi Pendidikan Biologi, FKIP Universitas Mataram, Indonesia \\ *Email: $\underline{\text { liwa_ilhamdi@unram.ac.id }}$
}

Acceped: July 29 2021. Approved: July 31 2021. Published: Sept 042021

\begin{abstract}
The house toad (Duttaphrynus melanostictus) is a highly adaptable amphibian species commonly found in urban areas. On Lombok Island, this species has the highest abundance in non-forest habitat types. In their habit, amphibians function as predators of various kinds of insects and different types of invertebrates. There are several research reports on prey items from Duttaphrynus melanostictus, but information regarding its role as control of harmful insects is still limited, especially on the island of Lombok. On the other hand, science learning aims to introduce the surrounding environment to students. Therefore, integrating the roles of species commonly found in these settlements is a necessity. The purpose of this study was to analyze the potential of Duttaphrynus melanostictus as a pest control insect and its urgency in science learning, especially in elementary schools. The study was conducted using the gastric surgery analysis method. The frog's stomach was taken continuously until the data was saturated, i.e., the data obtained were the same as the previous surgeries. The results showed that Duttaphrynus melanostictus preyed on 14 types of insects. There are 12 species $(85.71 \%)$ of which are harmful insects. If classified, nine species (75\%) are insect pests, and three species (25\%) are disease vectors. Information on the role of this species can be applied for science lessons in elementary school. The appropriate topics are (1) the importance of balancing and preserving natural resources in the environment and (2) the relationship between ecosystem components and food webs in the surrounding environment.
\end{abstract}

Keywords: Duttaphrynus melanostictus, elementary science lessons, harmful insects

\section{PRELIMINARY}

The interaction between predators and prey in their habitat is an essential aspect of the autecological study of amphibian species. On the island of Lombok, 12 species of amphibians were found, and one of them was Duttaphrynus melanostictus [1-2]. This species has high adaptability and is commonly found in residential areas [3]. It was found that this species had the highest abundance in non-forest habitat types compared to secondary and primary forests [4]. This species is also known as an amphibian which has a strong association with human activities. These factors caused it not to be found in primary forests. However, this species is also found in the primary forests of Senaru, Kembang Kuning, and Joben [5].

Differences in habitat types, secondary and primary forests, can affect the types of natural food for amphibian species [6]. Generally, amphibians prey insects [7]. Other prey is earthworms and various types of small arthropods [8]. Some relatively large amphibians prey snakes [9], and other smaller amphibians [10]. Besides being predators, there are also amphibian species that are herbivorous [11]. In the larval/tadpole phase, amphibian nutrition sources are microplankton and detritus [12]. This ecological function causes amphibians to have an essential role in terrestrial and aquatic habitats. Amphibians also play an important role in biogeochemical cycles and energy flow from aquatic habitats to terrestrial habitats and vice versa.

One of the amphibian species that plays an essential role in this ecological process is Duttaphrynus melanostictus. This species can adapt better than other amphibian species in habitats disturbed by human activities [13]. This ability gives it the advantage that its population can continue to grow in urban areas. In terms of the reduced threat of predators by human activities and the phenomenon of settlement expansion, the population of Duttaphrynus melanostictus tends to increase. These abundant biological resources must be utilized optimally for the benefit of humans. Based on the research results, it is known that Duttaphrynus melanostictus is a predator of various types of insects [14-15].

The types of prey preyed on by Duttaphrynus melanostictus vary in each habitat. Duttaphrynus melanostictus found in horticultural areas can be an insect pest because various insect pests are found in its stomach [14]. Judging from these two factors, there is a chance that the types of insects that Duttaphrynus melanostictus prey on in the habitat on Lombok Island are different from other areas, and there is a chance that some of them are harmful insects. To find out, a study related to this is needed. On the other hand, science education for students also aims to introduce the surrounding environment to them. 
Based on the elementary science curriculum, introducing students to their surroundings is expressed in content standards. Content standards are minimum competencies that students must master. Many essential competencies in knowledge and skill aspects must be mastered while studying in grades IV to grade VI [16]. Studies are needed to acquaint students with their environment, and the results are integrated into the science learning process. It has a positive impact, such as increased activity, learning outcomes, and students' scientific literacy [17-19].

The positive impact of integrating the research results is not directly proportional to its use in science lessons at school. When viewed from books, which are the main media in elementary schools, there are topics or subtopics of science unrelated to the environment around students-for example, the discussion about rare animals. In the results of the analysis of the fourth-grade book, it was also found that it had not optimally supported science learning through a scientific approach [20]. Several factors are causing it. Two of them are (1) limited information due to the limited quantity of research and (2) the integration of small research results into science lessons.

The low quantity and utilization of research results in science lessons impact amphibians not well known in Indonesia [21]. In Lombok, in particular, the number of studies that have been conducted is no more than ten. It consists of research for final projects such as undergraduate and postgraduate thesis and publications through journals and proceedings. At the same time, the potential for information about amphibians to be integrated into science learning is quite large. One species with this potential is Duttaphrynus melanostictus, highly associated with human activities [13].

Based on these facts, we conducted a study to obtain data regarding the potential of Duttaphrynus melanostictus as a controller for harmful insects. This probability information will then be analyzed to be integrated into science lessons in elementary school. The benefits of the results of this study include (1) providing information about the types of insects that are natural food for Duttaphrynus melanostictus in their habitat, (2) a reference source to increase the quantity of amphibian research in Lombok, and (3) a source of information or teaching materials for educators such as elementary school teachers or science education lecturers in the Primary School Teacher Education Study Program.

\section{RESEARCH METHODS Study site}

The study was conducted in the village of Kekait, Gunungsari District, West Lombok Regency, NTB (Figure 1). Kekait Village can be reached for 20-30 minutes from Mataram City, the capital city of NTB Province. This village has agricultural areas such as rice fields and people's plantations. People use their yard to plant several types of cultivated plants such as chili, ornamental plants, vegetable plants, and fruit plants. The altitude of Kekait village ranges from $300-600$ masl.

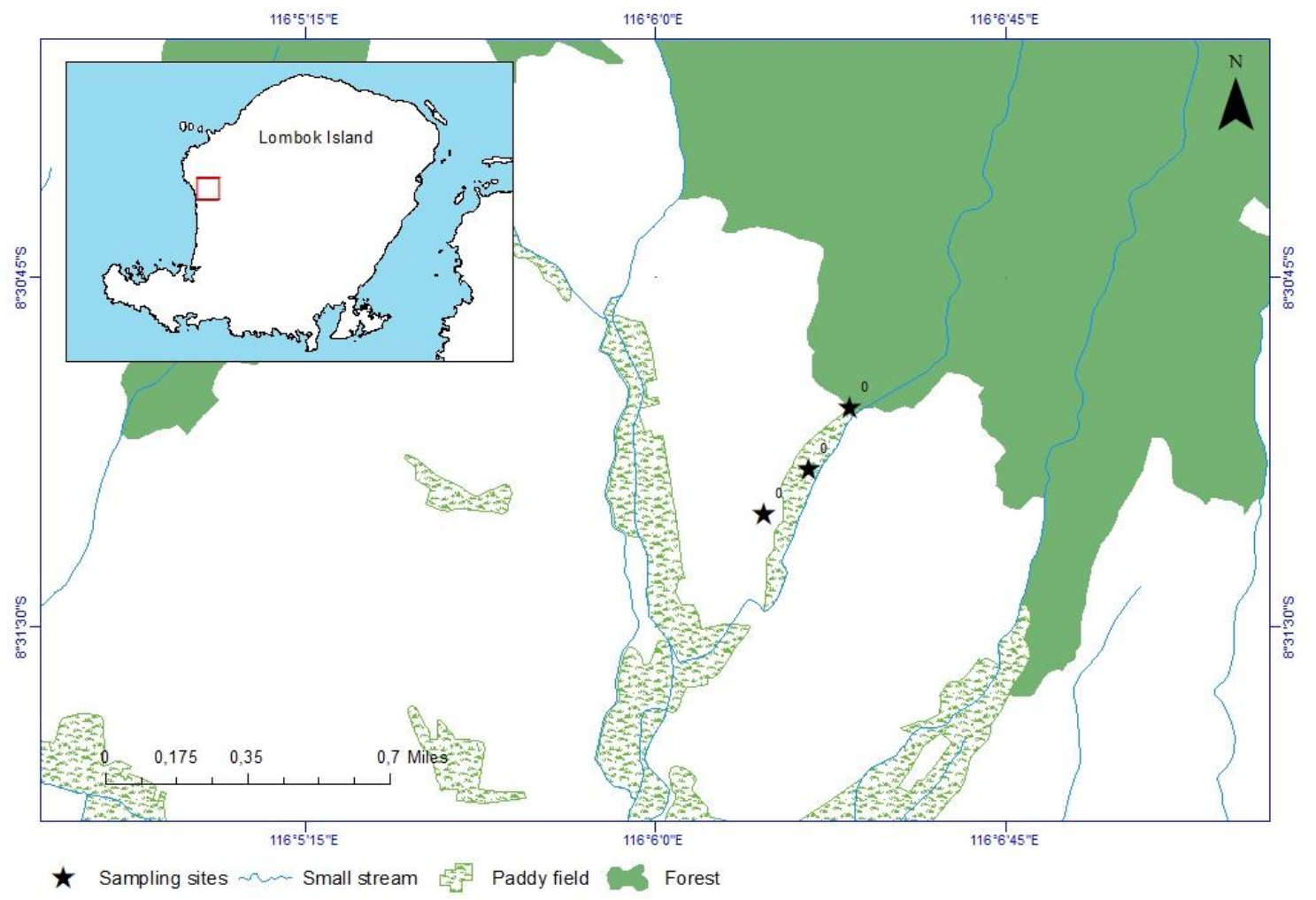

Figure 1. Study site. 
Table 1. Tools and materials used in the study and their functions.

\begin{tabular}{cll}
\hline No. & Tools and materials & Functions \\
\hline 1 & Torch & Lighting device when looking for house frogs in the field \\
2 & Tissue & Place to drip some chloroform during anesthesia \\
3 & Chloroform & Drugged the caught frog \\
4 & injection & Inject alcohol into the frog's brain \\
5 & Scissors & Dissection of the frog's stomach and removal of the stomach \\
6 & Glass bottle & Frog stomach preservation \\
7 & $70 \%$ alcohol & Preserving frog stomachs before laboratory analysis \\
8 & Petri dish & Place to put the contents of the stomach to be analyzed \\
9 & Pipette & Transferring alcohol \\
10 & Binocular Microscope & Identification tool for insect morphology \\
\hline
\end{tabular}

\section{Tools and materials}

This study used several tools and materials (Table 1). In general, tools and materials are based on the needs in the field and laboratory.

\section{Specimen's handling}

The capture of house frogs is carried out in residential, agricultural, and plantation areas at 8.00 - $9.30 \mathrm{pm}$ in the evening in GMT+8 time. Site selection is based on the habitat type of the house frog and is a valuable resource for the community. The selection of the capture time is based on the assumption that during the evening $-8.00 \mathrm{pm}$, the house frogs have received food. Between $8.00-$ $9.30 \mathrm{pm}$, most of the food is not completely digested. Every frog caught, the stomach is taken and preserved using $70 \%$ alcohol before identifying the contents.

\section{Stomach content identification}

Insect identification was carried out under a stereomicroscope. All morphological characters were recorded to facilitate species determination. Determination of insect species refers to [22].

\section{Substitution in elementary science lessons}

The potential probability of house toads as harmful insect controllers in science education was measured in three stages. The first one is analyzing the elementary science curriculum. The analysis was conducted qualitatively on the content standards, basic competencies of aspects of knowledge, and skills for grades IV, V, and VI. The document reviewed at this stage is Permendikbud Number 37 of 2018. The results of this analysis are a number of potential basic competencies integrated with the results of research on the potential of house frogs as harmful insect controllers. The integration uses a comparative method as used by [23]. Secondly is the determination of the degree of relationship between research results and potential essential competencies. This process involves three lecturers of Science Education in providing an assessment of the size of the relationship.

\section{RESULTS AND DISCUSSIONS}

Types of insects preyed on by Duttaphrynus melanostictus are 14; 12 types of which are harmful insects. If classified based on their roles for humans, the 12 types of harmful insects are divided into 2, pest insects and disease vector insects. Pest insects consist of 9 species, while disease vector insects are 3 (Figure 2). This potential helps humans in suppressing the population of their natural competitors. The existence of competitors is caused by the scope of the niche, both in terms of conditions and resources. In pests, the ecological niche that humans are in contact with is a food resource to obtain energy. Therefore, they are considered as harmful insects.

The interaction between humans and harmful insects is competition for the use of resources. Another interaction that can harm humans is parasitism. Ecologically, these interactions can reduce the abundance of both or one of the populations. Insects that use essential resources for humans are called pest insects. Pests themselves have been widely reported to cause disadvantages to farmers because of attacking cultivated plants. Some of them are Spodoptera frugiperda in Lampung and Bengkulu [24-25], Spodoptera litura in South Sulawesi, which caused damage and loss of three soybean varieties [26], and whitefly (Aleurodicus dugesii which attacks horticultural crops [27]. 
Other Insects:

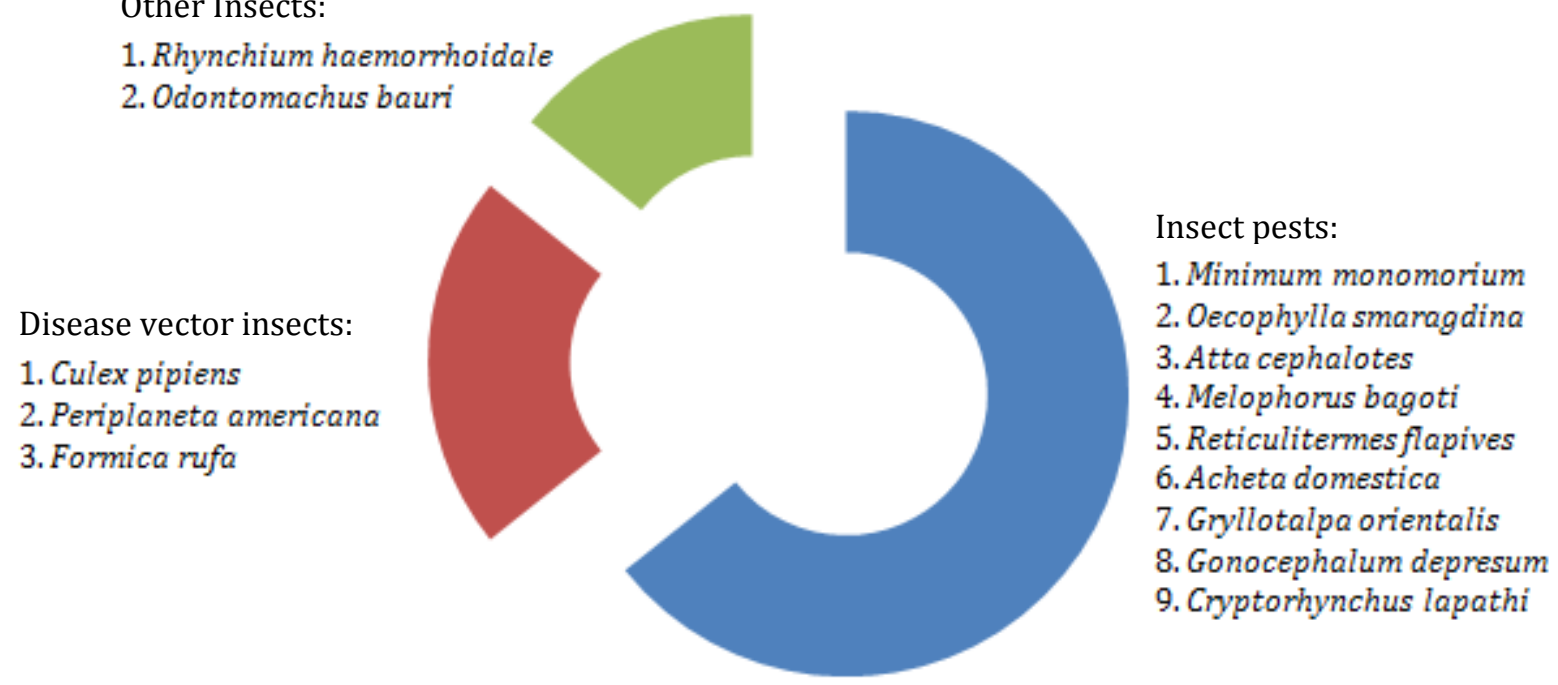

Figure 2. Composition of insect species preyed by Duttaphrynus melanostictus.

The harm caused by pest insects found in Duttaphrynus melanostictus's stomach damages cultivated crops, stored food, and properties (Table 2). 5 species become pests in the house because they cause damages food supplies and wooden household furniture. The other four species are those in agricultural and plantation areas. The explosion of pest populations has reportedly caused great harm to humans [28]. In addition, its nature to use foodstuffs as a source of nutrients and stored energy causes these types of insects to harm. Similarly, it damages properties made of wood such as windows, doors, and sills.

On the other hand, the pathogens carried by disease vector insects consist of bacteria, viruses, and parasitic worms (Table 3). Two of the three species of disease vector insects that become the natural prey of Duttaphrynus melanostictus Culex pipiens and Periplaneta americana - are species commonly known by people. Both species are popular for their intrusive roles. Not only carrying pathogens but the presence of such insects is also identified with unhealthy environmental conditions. As a solution, not a few people use certain chemicals, which are proven to be not good for health if used continuously [29]. At the same time, Formica rufa is not very well known. This type of ant is rarely found in a house.

Table 2. Types of pest insects and harms incurred

\begin{tabular}{cll}
\hline No & Species Names & Harms Incurred \\
\hline 1 & Minimum monomorium & Spoiling stored food \\
2 & Oecophylla smaragdina & Rolling leaves \\
3 & Atta cephalotes & Spoiling stored food \\
4 & Melophorus bagoti & Spoiling stored food \\
5 & Reticulitermes flapives & Damaging furniture made of wood \\
6 & Acheta domestica & Eating plant roots \\
7 & Gryllotalpa orientalis & Eating plant roots \\
8 & Gonocephalum depresum & Pests of gogo rice, coffee, sugar cane and potatoes \\
9 & Cryptorhynchus lapathi & Damaging flowers and cotton fruit \\
\hline
\end{tabular}

Table 3. Vector disease insects, pathogens, and harms incurred

\begin{tabular}{clll}
\hline No & Types of Insects & Pathogen & Diseases Caused \\
\hline 1 & Culex pipiens & Virus & Japanese encephalitis, meningitis, urticarial \\
2 & Periplaneta americana & Streptococcus, & Dysentery, diarrhea, cholera, hepatitis A, polio \\
& & Salmonella, worm & \\
3 & Formica rufa & CBPV & paralyzed \\
\hline
\end{tabular}

As herpetofauna that makes pest insects and disease vector insects a prey, Duttaphrynus melanostictus can be used as a natural pesticide.
The need for natural pesticides occurs because synthetic pesticides are harmful to the environment [30]. Damages of abiotic ecosystem components 
lead to a decrease in biodiversity. The use of synthetic pesticides also drastically decreases predator populations and triggers an explosion of specific pest populations. The use of insect poison in a house has been reported to cause deterioration of human health [31].

Judging from the ecological functions that are directly beneficial to humans, Duttaphrynus melanostictus needs to be conserved. Some of the actions that implement this activity include (1) not destroying the habitat and (2) not hunting \& killing Duttaphrynus melanostictus. Conservation itself will be more effective and efficient if the community is aware of the importance of this effort. This awareness can have a positive impact on the quantity and quality of action in their respective neighborhoods. One of the efforts that can be done to increase public awareness is to introduce as early as possible the role of Duttaphrynus melanostictus in the environment. For example, through science lessons to students who are still in elementary school.

Melanostictus as a pest control agent could be substituted for science lessons at the elementary school level. This concept can be substituted into 12 potential basic competencies and 6 topics (Table 4). The twelve basic competencies consist of 6 related to knowledge aspects and 6 skill aspects. The basic competencies are distributed in grade IV (6 basic competencies), grade V (4 basic competencies), and grade VI (2 basic competencies) of elementary school. Of the FGD result, it is known that the most suitable topics to be substituted are basic competencies 3.5 and basic competencies 4.5, "relationships between ecosystem components and food webs in the surrounding environment". The topics that are also appropriate are basic competencies 3.8 and basic competencies 4.8, "the importance of efforts to balance and preserve natural resources in the environment".

The topic "relationships between ecosystem components and food webs in the surrounding environment" consists of two subtopics: (1) relationships between ecosystem components in the surrounding environment and (2) food webs in the surrounding environment. The potential concept of Duttaphrynus melanostictus as a pest control agent can be substituted through these 2 subtopics. From the concept, which is an aspect of the science product, it is known that Duttaphrynus melanostictus is one of the components that set the ecosystem of the surrounding environment because it is generally found in residential areas [3], in habitats with types of ecosystems disturbed by humans such as rice fields, gardens, and secondary forests. This species is most abundant in non-forest habitat types on Lombok Island compared to secondary and primary forests [4].

Table 4. Basic competencies can be substituted for the potential concept of Duttaphrynus melanostictus as a pest control insect.

\begin{tabular}{|c|c|c|c|c|}
\hline No & $\mathrm{KD}$ & Elementary Science topic & $\begin{array}{c}\text { Level of } \\
\text { Conformity }\end{array}$ & Category \\
\hline \multicolumn{5}{|c|}{ Grade IV } \\
\hline 1 & $\begin{array}{l}\text { KD } 3.1 \\
\text { KD } 4.1\end{array}$ & $\begin{array}{l}\text { The relationship between form and function of body } \\
\text { parts in animals and plants }\end{array}$ & 1 & Very low \\
\hline 2 & $\begin{array}{l}\text { KD } 3.2 \\
\text { KD } 4.2\end{array}$ & $\begin{array}{l}\text { The life cycle of several types of living things and their } \\
\text { association with conservation efforts }\end{array}$ & 1 & Very low \\
\hline 3 & $\begin{array}{l}\text { KD } 3.8 \\
\text { KD } 4.8\end{array}$ & $\begin{array}{l}\text { The importance of balancing and preserving natural } \\
\text { resources in the environment }\end{array}$ & 4 & High \\
\hline \multicolumn{5}{|c|}{ Grade V } \\
\hline 4 & $\begin{array}{l}\text { KD 3.3; } \\
\text { KD } 4.3\end{array}$ & $\begin{array}{l}\text { Digestive organs and their functions in animals and } \\
\text { humans and how to maintain the health of human } \\
\text { digestive organs }\end{array}$ & 3 & Average/Enough \\
\hline 5 & $\begin{array}{l}\text { KD 3.5; } \\
\text { KD 4.5 }\end{array}$ & $\begin{array}{l}\text { Relationships between ecosystem components and food } \\
\text { webs in the surrounding environment }\end{array}$ & 5 & Very high \\
\hline \multicolumn{5}{|c|}{ Grade VI } \\
\hline 6 & $\begin{array}{l}\text { KD } 3.3 \text {; } \\
\text { KD } 4.3\end{array}$ & How living things adapt to their environment & 2 & Low \\
\hline
\end{tabular}

As an ecosystem component, Duttaphrynus melanostictus performs predation interactions with various insects because it utilizes biotic components as a source of nutrition and energy. There are several species compositions of prey insects, in contrast to previous findings [1415]. These facts indicate that (1) this species can utilize more insect species than previously known,
(2) high adaptation in utilizing various types of feed resources for survival in various types of habitats, and (3) natural food of Duttaphrynus melanostictus is predominated by insects, like other amphibian species [32]. The interaction with these insects can be substituted into a subtopic discussion of the relationship between ecosystem components. 
Its relationship in the form of predation with insects involves the transfer of matter and energy, so this concept can also be substituted into the subtopic of food webs in the surrounding environment. After the matter and energy moved to Duttaphrynus melanostictus from its prey, naturally, some of the matter and energy returned to nature through the processes of respiration, parasitism, and decomposition. The natural predators of these amphibians are not certainly known, and they possibly do not exist because they can produce strong toxic substances [33]. However, predators include dragonfly larvae [34] and fisheating spiders [35]. It causes this species to have an important role as a medium that connects aquatic and terrestrial habitats.

Adult individuals of Duttaphrynus melanostictus are terrestrial-based on the substrates' analysis for their activities [5]. As a species in which various insects are found in its stomach, Duttaphrynus melanostictus is an ecosystem component that maintains the balance of the surrounding environment. Its function as an agent of density-dependent factors can prevent the population explosion of various types of insects that become their prey. Insect preyed upon species are predominated by harmful insects, making them a biological resource that requires genuine conservation efforts and actions. From this point of view, of course, it can be transferred through science lessons on the topic "The importance of balancing and preserving natural resources in the environment".

The substitution of science products from the research results of Duttaphrynus melanostictus itself can realize one of the goals of science learning; introduce the surrounding environment to students in elementary school. This substitution in the future will produce common knowledge among the community, and it is hoped that it can increase mutual awareness of the importance of conservation efforts. In school learning, the use of the surrounding environment can increase the science learning activities of elementary school students [17]. Learning that utilizes the surrounding environment can also improve learning outcomes on organism interaction topics [18] and enhance student literacy [19]. The surrounding environment can be a learning resource, and science learning laboratory [36-38].

\section{CONCLUSION}

This study succeeded in revealing that the house frog (Duttaphrynus melanostictus) has the potential as a density-dependent factor for various types of harmful insects. These destructive insects are insect pests and disease vector insects. This science product can be substituted into science lessons for students at the elementary level. Appropriate topics are (1) the importance of balancing and preserving natural resources and (2) the relationship between ecosystem components and food webs in the surrounding environment.

\section{REFERENCES}

[1] Monk, K. A., De Fretes, Y., \& ReksodiharjoLilley, G. (2000). Ekologi Nusa Tenggara dan Maluku. Jakarta: Prenhallindo.

[2] Syazali, M., Idrus, A. Al, \& Hadiprayitno, G. (2016). Kekayaan spesies amfibi di Pulau Lombok, Indonesia. Proceeding Biology Education Conference, 13(1), 730-735.

[3] Moore, M., Francois, J., Niaina, S., \& Edmonds, D. (2015). The new toad in town: Distribution of the Asian toad, Duttaphrynus melanostictus, in the Toamasina area of eastern Madagascar Invasive species are among the greatest threats to biodiversity and of utmost concern to conservationists. Tropical Conservation Science, 8(2), 440-455.

[4] Syazali, M., Idrus, A. Al, \& Hadiprayitno, G. (2019). Habitat characteristic and conservation of amphibians in Lombok Island. Biota: Jurnal Biologi Dan Pendidikan Biologi, 12(2), 98107. https://doi.org/10.20414/jb.v12i2.210

[5] Septian, I. G. N. (2016). Keanekaragaman Amphibia (Ordo Anura) dan Preferensi Makanan Dua Spesies Limnonectes (L. kadarsani dan L. dammermani) di Taman Nasional Gunung Rinjani Lombok. Institut Pertanian Bogor.

[6] Caldas, F. L. S., da Silva, B. D., dos Santos, R. A., de-Carvalho, C. B., Santana, D. O., Gomes, F. F. A., \& Faria, R. G. (2016). Autoecology of Phyllomedusa nordestina (Anura: Hylidae) in areas of the Caatinga and Atlantic Forest in the State of Sergipe, Brazil. North-Western Journal of Zoology, 12(2), 271-285.

[7] Sarathchandra, R. B. L. R., Vandercone, R. P. G., \& Ukuwela, K. D. B. (2016). Some aspects of dietary ecology of a community of amphibians in the Mihinthale Sanctuary, North Central province, Sri Lanka. Proceedings of the Third Undergraduate Research Symposium on Zoology \& Environmental Management.

[8] Norval, G., Huang, S., Mao, J., Goldberg, S. R., \& Yang, Y.-J. (2014). Notes on the diets of five amphibian species from Southwestern Taiwan. ALYTES: International Journal of Batrachology, 30, 69-77.

[9] Shea, M. O., Kathriner, A., Mecke, S., Sanchez, C., \& Kaiser, H. (2013). 'Fantastic Voyage': a live blindsnake (Ramphotyphlops braminus) journeys through the gastrointestinal system of a toad (Duttaphrynus melanostictus). Herpetology Notes, 6, 467-470.

[10] Measey, G. J., Vimercati, G., De Villiers, F. A., Mokhatla, M. M., Davies, S. J., Edwards, S., \& Altwegg, R. (2015). Frog eat frog: exploring variables influencing anurophagy. 
PeerJ, 3, e1204.

[11] da Silva, H. R., \& de Britto-Pereira, M. C. (2006). How much fruit do fruit-eating frogs eat? An investigation on the diet of Xenohyla truncata (Lissamphibia: Anura: Hylidae). Journal of Zoology, 270, 692-698.

[12] Babini, S., Martina, L. C., Luque, E., Gari, N., Salas, N., \& Martino, A. L. (2017). Anuran larvae diet from agroecosystem's ponds: environmental quality and implications for their populations. Journal of Limnology, 76(1): 137-147.

[13] Licata, F., Andreone, F., Freeman, K., Rabesihanaka, S., Robsomanitrandrasana, E., Reardon, J. T., \& Crottini, A. (2020). The Asian Toad (Duttaphrynus melanostictus) in Madagascar: A Report of an Ongoing Invasion. In Problematic Wildlife II (pp. 617638). Springer, Cham.

[14] Döring, B., Mecke, S., Kieckbusch, M., O'Shea, M., \& Kaiser, H. (2017). Food spectrum analysis of the Asian toad, Duttaphrynus melanostictus (Schneider, 1799)(Anura: Bufonidae), from Timor Island, Wallacea. Journal of Natural History, 51(1112), 607-623.

[15] Jhon, A. H., Jumilawaty, E., \& Girsang, A. A. (2018). Food preferences of anuran species in horticultural lands, Doulu village, Karo regency, North Sumatera. IOP Conference Sieries: Journal of Physics, 1116, 1-6. https://doi.org/10.1088/17426596/1116/5/052034.

[16] Permendikbud. (2018). Permendikbud RI Nomor 37 Tahun 2018 tentang Perubahan atas Peraturan Menteri Pendidikan dan Kebudayaan Nomor 24 Tahun 2016 tentang Kompetensi Inti dan Kompetensi Dasar Pelajaran pada Kurikumlum 2013 pada Pendidikan Dasar dan Pendidikan Menengah (No. 37). Salinan Permendikbud.

[17] Kurniawati, A., \& Mawardini, A. (2017). Implementasi Pembelajaran berbasis Pemanfaatan Lingkungan Sekitar untuk Meningkatkan Aktivitas Belajar IPA SD. Indonesian Journal of Primary Education, 1(2), 39-50.

[18] Nuraini, N., Ridhwan, M., \& Azwir, A. (2020). Pengaruh pemanfaatan lingkungan sekolah terhadap peningkatan hasil belajar siswa pada materi ajar interaksi makhluk hidup dengan lingkungan di smp negeri 2 mesjid raya kabupaten aceh besar. Jurnal Biology Education, 8(2): 74-81.

[19] Kristyowati, R., \& Purwanto, A. (2019). Pembelajaran literasi sains melalui pemanfaatan lingkungan. Scholaria: Jurnal Pendidikan Dan Kebudayaan, 9(2), 183-191.

[20] Limiansih, K. (2016). Analisis buku: Apakah kegiatan di buku siswa kelas iv sd kurikulum
2013 telah mendukung pembelajaran IPA dengan pendekatan saintifik?. In Prosiding Seminar Nasional Inovasi Pendidikan.

[21] Iskandar, D. T., \& Erdelen, W. R. (2006). Conservation of amphibians and reptiles in Indonesia: issues and problems. Amphibian and reptile Conservation, 4(1), 60-87.

[22] Borror, D. J., Triplehon, C.A., and Johnson, N. F. (1992). Pengenalan Pelajaran Serangga (Yogayakarta: Gadjah Mada University Press) Edisi Keenam.

[23] Sulaeman, N. F., Nuryadin, A., Widyastuti, R., \& Subagiyo, L. (2020). Air Quality Index and the Urgency of Environmental Education in Kalimantan. Jurnal Pendidikan IPA Indonesia, 9(3), 371-383.

[24] Trisyono, Y. A., Suputa, S., Aryuwandari, V. E. F., Hartaman, M., \& Jumari, J. (2019). Occurrence of heavy Infestation by the fall armyworm Spodoptera frugiperda, a new alien invasive pest, in corn Lampung Indonesia. Jurnal Perlindungan Tanaman Indonesia, 23(1), 156-160.

[25] Zarkani, A., Wibowo, R. H., \& Sipriyadi, S. (2020). New invasive pest, Spodoptera frugiperda (JE Smith)(Lepidoptera: Noctuidae) attacking corns in Bengkulu, Indonesia. Serangga, 25(1).

[26] Fattah, A., Sjam, S., Diana Daud, I., Sartika Dewi, V., \& Ilyas, A. (2020). Impact of armyworm Spodoptera litura (Lepidoptera: Noctuidae) attack: Damage and loss of yield of three soybean varieties in South Sulawesi, Indonesia. Journal of Crop Protection, 9(3), 483-495.

[27] Hidayat, P., Maryana, E., Kusumah, Y. M., \& Nurulaila, L. (2020, March). Host range and population density of the giant whitefly Aleurodicus dugesii Cockerell (Hemiptera: Aleyrodidae) on horticultural crops in Cipanas-Cianjur, West Java, Indonesia. In IOP Conference Series: Earth and Environmental Science (Vol. 468, No. 1, p. 012008). IOP Publishing.

[28] Perhimpunan Entomologi Indonesia. (2017). Ledakan Hama atau yang Dikenal dengan Outbreak. Diakses dari https://peipusat.org/berita/14/ledakan-hama-atau-biasadikenal-dengan.html pada tanggal 20 Juni 2021.

[29] Rahmalia, D. (2017). Penggunaan dan Bahaya Insektisida Rumah Tangga di Kelurahan Meranti Pandak Kecamatan Rumbai Pesisir Kota Pekanbaru. JUKMAS: Jurnal Untuk Masyarakat Sehat, 1(1), 69-75.

[30] Fuad, M. M., Junaidi, A. B., Habibah, A., Hamzah, J., Toriman, M. E., Lyndon, N., ... \& Azima, A. M. (2012). The impact of pesticides on paddy farmers and ecosystem. Advances in Natural and Applied Sciences, 
6(1), 65-70.

[31] Roghelia, V., \& Patel, V. H. (2017). Effect of pesticides on human health. Research \& Reviews: A Journal of Health Professions, 7(2), 30-40.

[32] Díaz, J. A., Sugai, J. L. M. M., Ceron, K., Moroti, M. D. T., \& Santana, D. J. (2020). Dietary selectivity and sexual size dimorphism of Chiasmocleis mehelyi (Anura: Microhylidae) in a Cerrado area of southwest Brazil. North-Western Journal of Zoology, 16(2): 166-171.

[33] David, M., \& Kartheek, R. M. (2015). Malathion acute toxicity in tadpoles of Duttaphrynus melanostictus, morphological and behavioural study. The Journal of Basic \& Applied Zoology, 72, 1-7.

[34] Mogali, S. M., Saidapur, S. K., \& Shanbhag, B. A. (2020). Behavioral responses of tadpoles of Duttaphrynus melanostictus (Anura: Bufonidae) to cues of starved and fed dragonfly larvae. Phyllomedusa: Journal of Herpetology, 19(1), 93-98.

[35] Jithin, V., Devarajan, A., \& Dharmaraj, J. (2021). Predation on Asian Common Toad, Duttaphrynus melanostictus (Lütken, 1864)(Anura: Bufonidae), tadpoles by a Fisheating Spider, Nilus sp.(Araneae: Pisauridae). Reptiles \& Amphibians, 28(1), 56-58.

[36] Al Bahij, A., Santi, A. U. P., \& Prastiwi, D. A. (2018, July). Pemanfaatan lingkungan alam sekitar sebagai media ajar di Sekolah Dasar Negeri 2 Sirah Pulo Padang. In Prosiding Seminar Nasional Pendidikan (Vol. 1, No. 1).

[37] Lestari, E. (2018). Pemanfaatan lingkungan alam sebagai sumber belajar pada pembelajaran ipa di kelas iv sd alam baturraden (Doctoral dissertation, IAIN).

[38] Budiyono, M., Haryono, M., Utanto, Y., \& Subkhan, E. (2018, February). Educational technologist competencies at school. In 1st International Conference on Education Innovation (ICEI 2017) (pp. 51-55). Atlantis Press. 